\title{
Classification of acidophilic, neutrotolerant and neutrophilic streptomycetes by nucleotide sequencing of 5S ribosomal RNA
}

\author{
Yong-Ha Park, ${ }^{1 *}$ Dong-Gu Yim, ${ }^{1}$ Eunjoon Kim, ${ }^{1}$ Yung-Hee Kho, ${ }^{1}$ Tae-ICK Mheen, ${ }^{1}$ \\ JOHN LONSDALE ${ }^{2}$ and MICHAEL GOODFELLOW ${ }^{2}$ \\ ${ }^{1}$ Korean Collection for Type Cultures, Gene Bank, Genetic Engineering Research Institute, Korea Institute of Science and \\ Technology, PO Box 17, Daeduk Science Park, Daejeon 305-606, Republic of Korea \\ ${ }^{2}$ Department of Microbiology, The Medical School, Framlington Place, Newcastle upon Tyne NE2 4HH, UK
}

(Received 25 February 1991; accepted 28 May 1991)

\begin{abstract}
Complete 5S ribosomal RNA sequences were obtained for four acidophilic actinomycetes, seven neutrophilic streptomycetes and a strain of Streptoverticillium baldaccii. All of the organisms contained RNAs belonging to the 120 nucleotide type. An evolutionary tree was generated after combining the test data with results from similar studies on representative Gram-positive bacteria. The acidophilic, neutrotolerant and neutrophilic actinomycetes were recovered in a distinct cluster that was equated with the genus Streptomyces. The sequence data support the view that the genera Chainia, Elytrosporangium, Kitasatoa and Microellobosporia should be considered as synonyms of the genus Streptomyces. The recovery of the Streptoverticillium baldaccii strain on the fringe of the Streptomyces cluster is also consistent with current trends in the taxonomy of these organisms. Further work is needed to determine the taxonomic status of the two streptomycete subgroups that comprised the streptomycete cluster.
\end{abstract}

\section{Introduction}

The genus Streptomyces is currently defined using a combination of chemical, morphological and physiological properties (Williams et al., 1989). The genera Actinopycnidium, Actinosporangium, Chainia, Elytrosporangium, Kitasatoa and Microellobosporia have been distinguished from Streptomyces by morphological criteria, but they share many other phenotypic properties with Streptomyces and have therefore been proposed as synonyms of this genus (Goodfellow et al., 1986, a-d). The genus Streptoverticillium can be distinguished from Streptomyces by its verticillate sporophores but in other respects has many characters in common with streptomycetes. In an extensive numerical taxonomic survey (Williams et al., 1983), numerous type strains of Streptomyces and related taxa were assigned to 23 major (six or more strains), 20 minor (two to five strains) and 25 single-membered clusters. The minor and single-membered clusters were considered as species and the major clusters regarded as species-groups.

\footnotetext{
The nucleotide sequence data reported in this paper have been submitted to GenBank and have been assigned the accession numbers M59335-M59346 inclusive.
}

Members of validly described Streptomyces species behave as neutrophiles in culture, growing between pH 5.0 and 9.0 with an optimum close to neutrality. Acidophilic and neutrotolerant actinomycetes with phenotypic properties characteristic of Streptomyces have been isolated from acidic habitats, notably soil (Williams et al., 1971; Khan \& Williams, 1975; Goodfellow \& O'Donnell, 1989). Acidophilic isolates grow in the range from about $\mathrm{pH} 3.5$ to 6.5 , with optimum rates at $\mathrm{pH} 4.5$ to 5.5 , and their neutrotolerant counterparts between $\mathrm{pH} 3.5$ and 7.5 , but optimally around $\mathrm{pH} 5 \cdot 5$. Acidophilic and neutrophilic actinomycetes have not been the subject of objective comparative studies though members of the two groups have been separated using numerical taxonomic procedures (Khan \& Williams, 1975; Williams et al., 1983).

5S ribosomal RNA sequencing has been used to establish evolutionary relationships between diverse prokaryotes including Micrococcus and Staphylococcus spp. (Dekio et al., 1984), Mycoplasma spp. (Rogers et al., 1985), Thiobacillus and Thiomicrospora (Lane et al., 1985), the Vibrionaceae (MacDonell \& Colwell, 1985), and coryneform actinomycetes (Park et al., 1987a,b). In the present work representative strains of acidophilic actino- 
Table 1. Source and taxonomic histories of test strains

\begin{tabular}{|c|c|c|}
\hline $\begin{array}{l}\text { Laboratory } \\
\text { number }\end{array}$ & Name and cluster $\dagger$ & Source $\ddagger$ \\
\hline${ }^{*} \mathrm{KCTC} 9080$ & S. griseus subsp. griseus & JCM 4047; KCC-S 0047; Y. Okami, NIHJ 106; IMRU 3463 \\
\hline *KCTC 9079 & S. griseus subsp. cretosus & JCM 4742; KCC-S 0742; IFO 13457; SAJ; ISP 5561; CBS 137.21 \\
\hline${ }^{*} \mathrm{KCTC} 9065$ & S. sclerotialus (syn. Chainia antibiotica) & $\begin{array}{l}\text { JCM } 3039 ; \text { KCC A-0039; H. A. Lechevalier, 3750; M. J. Thirumalachar; soil, } \\
\text { Poona, India }\end{array}$ \\
\hline${ }^{*}$ KCTC 9066 & S. cinereus (syn. Microellobosporia cinerea) & $\begin{array}{l}\text { JCM 3040; KCC A-0040; IMRU 3855; H. A. Lechevalier, 3855; soil, Pilta, } \\
\text { Malta }\end{array}$ \\
\hline КСТC 9075 & S. purpureus (syn. Kitasatoa kauaiensis) & $\begin{array}{l}\text { JCM } 3177 \text {; KCC A-0177; A. Matsuame, KI-100027; T. Hata, KA281; soil, } \\
\text { Kauai Island, Hawaii, USA }\end{array}$ \\
\hline KCTC 9142 & S. diastaticus & NCIMB 9603; NRRL 2650 \\
\hline${ }^{*}$ KCTC 9071 & $\begin{array}{l}\text { S. brasiliensis (syn. Elytrosporangium } \\
\text { brasiliense) }\end{array}$ & $\begin{array}{l}\text { JCM 3086; KCC A-0086; IMUR 2572; J. C. Falcão de Morais, CCIB 71 ; soil, } \\
\text { Alianca, North of Pernambuco, Brazil }\end{array}$ \\
\hline КСТС 9091 & Acidophilic actinomycete (cluster 28) & JL 46, Hamsterley Forest, County Durham, UK, $A_{2}$ horizon \\
\hline КСТС 9092 & Acidophilic actinomycete (cluster 4 ) & JL 85, Hamsterley Forest, F horizon \\
\hline КСТC 9093 & Neutrotolerant actinomycete (cluster 30 ) & JL 338, East Cramlington Colliery, Northumberland, UK, coal waste \\
\hline КСТC 9094 & Acidophilic actinomycete (cluster 10) & JL 445, Woodhorn Colliery, Northumberland, UK, coal waste \\
\hline${ }^{*} \mathrm{KCTC} 9081$ & Streptoverticillium baldaccii & JCM 4272; KCC S-0272; IPV 174; soil, Arcinazzo, Italy \\
\hline
\end{tabular}

* Type strain.

† Clusters defined by Lonsdale (1985).

$\ddagger$ CBS, Centraalbureau voor Schimmelcultures, Baarn, The Netherlands; IFO, Institute for Fermentation, Yodogawa-ku, Osaka, Japan; IMRU, Waksman Institute of Microbiology, Rutgers, The State of University of New Jersey, Piscataway, NJ, USA; IPV, Institute of Plant Pathology, University of Milano, Milano, Italy; ISP, International Cooperative Project for Description and Deposition of Type Cultures of Streptomyces; JCM, Japan Collection of Micro-organisms, RIKEN, Wako-shi, Saitama, Japan; JL, John Lonsdale, Department of Microbiology, University of Newcastle, Newcastle upon Tyne, UK; KCC, KCC Culture Collection of Actinomycetes, Kaken Pharmaceutical Co. Ltd, Tokyo, Japan; KCTC, Korean Collection for Type Cultures, Genetic Engineering Research Institute, Korea Institute of Science and Technology, Daejon, Korea; NCIMB, National Collection of Industrial and Marine Bacteria, Aberdeen, UK; NIHJ, Department of Antibiotics, National Institute of Health of Japan, Tokyo, Japan; NRRL, ARS Culture Collection, Northern Regional Research Center, Peoria, IL, USA.

mycetes (Lonsdale, 1985) were compared with marker neutrophilic streptomycetes using data derived from $5 \mathrm{~S}$ rRNA sequencing studies.

\section{Methods}

Bacterial strains and culture conditions. The sources of the test strains are given in Table 1. The strains of Streptomyces brasiliensis, S. griseus, $S$. purpureus and $S$. sclerotialus were grown in yeast-starch medium (yeast extract, $0.2 \%, \mathrm{w} / \mathrm{v}$; soluble starch, $1.0 \%, \mathrm{w} / \mathrm{v}$ ) at $\mathrm{pH} 7 \cdot 3$. The acidophilic and neutrotolerant actinomycetes and $S$. diastaticus KCTC 9142 were grown in Bennett's broth (Jones, 1949), and $S$. cinereus KCTC 9066 and Streptoverticillium baldaccii KCTC 9081 in ISP media 3 and 4 (Difco), respectively. The organisms were grown in shake flasks at $30^{\circ} \mathrm{C}$ for $2 \mathrm{~d}$, then checked for purity and harvested by centrifugation.

Isolation and sequencing of $5 S$ rRNA. Wet biomass was homogenized with aluminium oxide, mixed with $\mathrm{Tris} / \mathrm{HCl}$ and DNAase, and the subsequent phenolized lysate treated by polyacrylamide gel electrophoresis, as previously described (Park et al., 1987a). The sequences were determined using both the chemical and enzymic methods (Peattie, 1979; Donis-Keller, 1980).

Phylogenetic analysis. Evolutionary distances ( $K_{\text {nuc }}$ values) were calculated after Kimura (1980). An evolutionary tree was generated using published procedures and data from earlier studies on representative Gram-positive bacteria (Park et al., 1987a). 5S rRNA secondary structure models were constructed using the method of Tinoco et al. (1971) as adapted by Hori \& Osawa (1986).

\section{Results and Discussion}

The 5S rRNA nucleotide sequences were aligned by juxtaposing the defined secondary structures and were divided into 15 regions (Fig. 1). A and $\mathrm{A}^{\prime}, \mathrm{B}$ and $\mathrm{B}^{\prime}, \mathrm{C}$ and $C^{\prime}$, and $D^{\prime}$ and $D^{\prime}$ are the sequences that can basepair with each other. The loop region aLb connects the base-paired regions $\mathrm{A}$ and $\mathrm{B}$; other based-paired regions are connected by bLc, $c L c^{\prime}, c^{\prime} \mathrm{Lb}^{\prime}, \mathrm{b}^{\prime} \mathrm{Ld}, \mathrm{dLd} \mathrm{d}^{\prime}$ and $\mathrm{d}^{\prime} \mathrm{La}^{\prime}$ as shown. The percentage sequence homology values are given in Table 2.

Ten of the twelve strains contained rRNA molecules 120 nucleotides long. The exceptions, $S$. sclerotialus KCTC 9065 and Stv. baldaccii KCTC 9081, had 5S rRNAs consisting of 121 and 122 nucleotides, respectively. On the basis of primary and secondary structure the $5 \mathrm{~S}$ rRNAs of the organisms tested belonged to the $120 \mathrm{~N}$ type (Hori \& Osawa, 1986). However, all of the rRNA sequences were found to have a bulge in the $A-A^{\prime}$ helix, and unique sequences, such as $5^{\prime}$-CUGCA-3' and $5^{\prime}$ UGUGG-3', in the helix D- $\mathrm{D}^{\prime}$ region. These properties have previously been reported from $5 S$ rRNA sequences of coryneform (pleomorphic) actinomycetes and from a strain of S. griseus (Park et al., 1987a, b; Simoncsits, 1980 ). The 5S rRNAs from $S$. diastaticus KCTC 9142, $S$. purpureus KCTC 9075, the $S$. griseus strains (KCTC 9079 


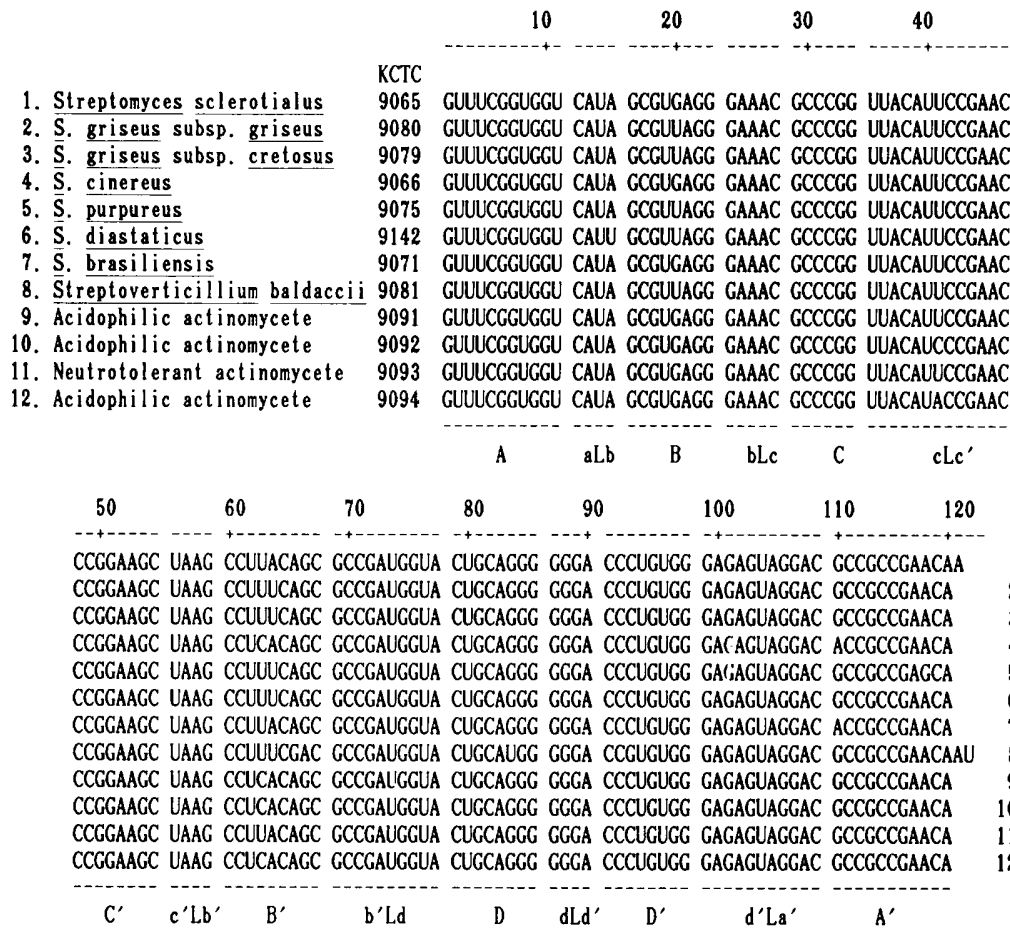

Fig. 1. Sequence alignment of $5 S$ rRNAs from 12 actinomycete strains. A, $A^{\prime}$, etc., base-paired regions; $a L b, b L c$, etc., loop regions.

Table 2. Homology percentage matrix of $5 S$ rRNA sequences

\begin{tabular}{|c|c|c|c|c|c|c|c|c|c|c|c|c|c|}
\hline & & 1 & 2 & 3 & 4 & 5 & 6 & 7 & 8 & 9 & 10 & 11 & 12 \\
\hline & KCTC & & & & & & & & & & & & \\
\hline 1. Streptomyces sclerotialus & 9065 & 100 & & & & & & & & & & & \\
\hline 2. S. griseus subsp. griseus & 9080 & 97 & 100 & & & & & & & & & & \\
\hline 3. S. griseus subsp. cretosus & 9079 & 97 & 100 & 100 & & & & & & & & & \\
\hline 4. $S$. cinereus & 9066 & 97 & 96 & 96 & 100 & & & & & & & & \\
\hline 5.S. purpureus & 9075 & 96 & 99 & 99 & 95 & 100 & & & & & & & \\
\hline 6. S. diastaticus & 9142 & 96 & 99 & 99 & 95 & 98 & 100 & & & & & & \\
\hline 7. S. brasiliensis & 9071 & 98 & 97 & 97 & 99 & 96 & 96 & 100 & & & & & \\
\hline 8. Streptoverticillium baldaccii & 9081 & 94 & 95 & 95 & 91 & 94 & 94 & 92 & 100 & & & & \\
\hline 9. Acidophilic actinomycete & 9091 & 98 & 97 & 97 & 99 & 96 & 96 & 98 & 92 & 100 & & & \\
\hline 10. Acidophilic actinomycete & 9092 & 97 & 96 & 96 & 98 & 95 & 95 & 97 & 91 & 99 & 100 & & \\
\hline 11. Neutrotolerant actinomycete & 9093 & 99 & 98 & 98 & 98 & 97 & 97 & 99 & 93 & 99 & 98 & 100 & \\
\hline 12. Acidophilic actinomycete & 9094 & 97 & 96 & 96 & 98 & 95 & 95 & 97 & 91 & 99 & 99 & 98 & 100 \\
\hline
\end{tabular}

and 9080) and Stv. baldaccii KCTC 9081 were characterized by the presence of double $\mathrm{U}-\mathrm{U}$ mismatches in the B-B' helix.

The phylogenetic tree (Fig. 2) generated from the 5S rRNA sequence data shows that the acidophilic, neutrotolerant and neutrophilic actinomycetes form a distinct evolutionary group that can readily be distinguished from the marker 'coryneform' actinomycetes and representatives of the genera Bacillus, Lactobacillus and Staphylococcus. It is evident, therefore, that acidophilic and neutrotolerant actinomycetes with a combination of chemical, morphological and physiological properties corresponding to those characteristic of neutrophilic streptomycetes should be assigned to the genus Streptomyces.
The proposals that the genera Chainia, Elytrosporangium, Kitasatoa and Microellobosporia become synonyms of the genus Streptomyces (Goodfellow et al., 1986a, b, c) are underlined by the sequence data. Similarly, the recovery of the $S t v$. baldaccii strain on the fringes of the Streptomyces cluster is in line with some previous studies. Streptomyces and Streptoverticillium can be distinguished on the basis of sporophore morphology (Williams et al., 1989) and by data from numerical taxonomic (Williams et al., 1983) and rRNA : DNA homology studies (Gładek et al., 1985).

The recovery of the streptomycetes and the streptoverticillium strain in a phylogenetically distinct taxon is in good agreement with corresponding evidence drawn from 16S rRNA cataloguing studies (Stackebrandt et al., 

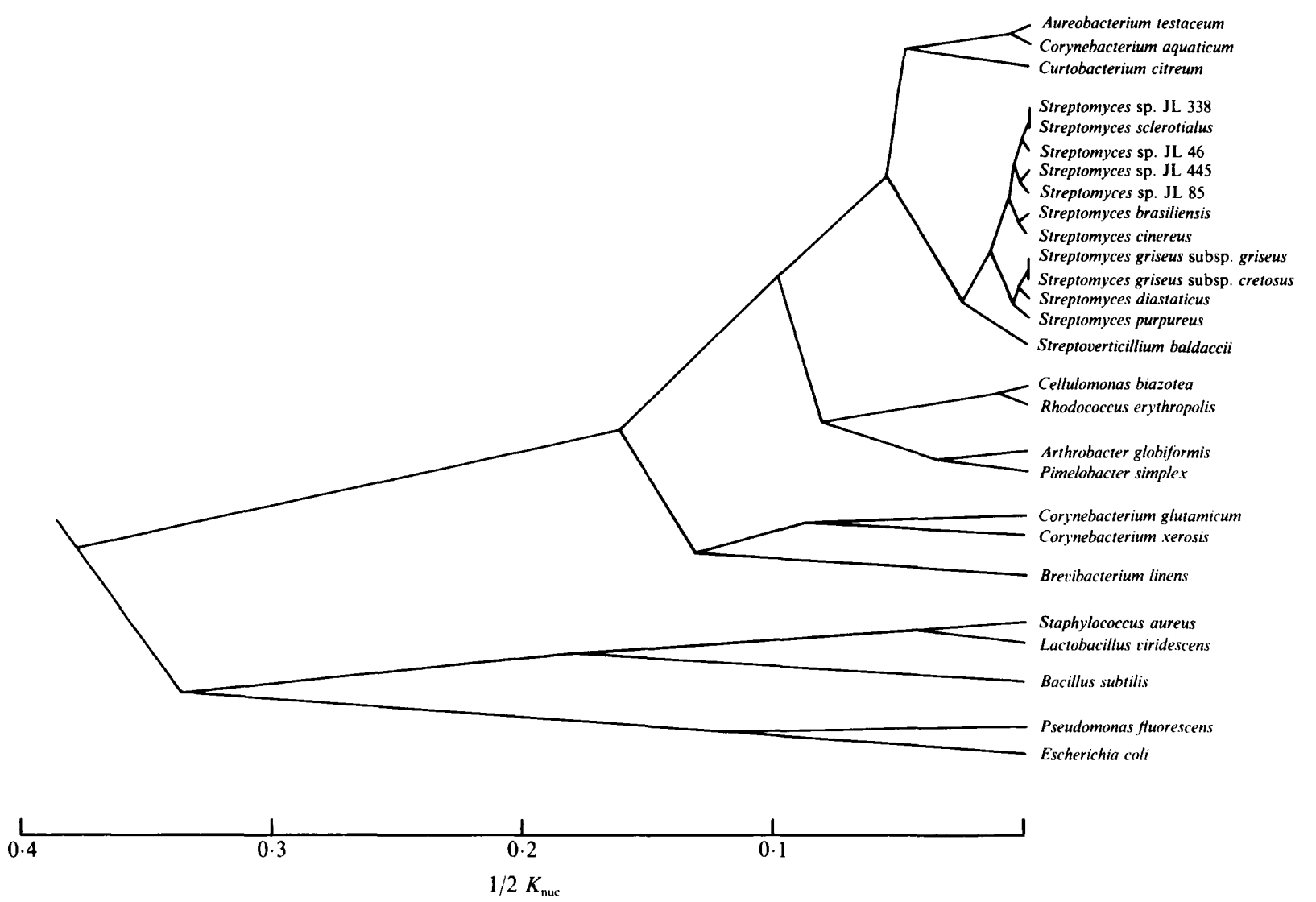

Fig. 2. Phylogenetic relationships among streptomycetes and selected Gram-positive and Gram-negative bacteria based on 5S rRNA sequence data.

1983). The taxon circumscribed using these rRNA data corresponds to the family Streptomycetaceae (Waksman \& Henrici, 1943). Further cooperative work, however, needs to be undertaken to determine the taxonomic status of the two streptomycete subgroups that were recognized (Fig. 2). The first subgroup contains the $S$. griseus strains, $S$. diastaticus KCTC 9142 and $S$. purpureus KCTC 9075, and the second subgroup $S$. brasiliensis KCTC 9071, $S$. cinereus KCTC 9066, $S$. sclerotialus KCTC 9065 and the acidophilic streptomycetes.

This research was supported by grant BSE7029-125-3 from the Ministry of Science \& Technology (MOST) of the Republic of Korea and by UNDP, ROK/87/018/A/01/12. One of us (J.L.) gratefully acknowledges receipt of a NERC studentship. We would also like to express our appreciation to Professor Yung-Chil Hah, Professor KookHee Kang and Dr Heui-il Kang for helpful suggestions and discussions. We also thank Kie-Jung Park, Keun-Chul Lee, and Moon-Soo Lee for their excellent computing and technical assistance.

\section{References}

Dekio, S., Yamasaki, R., JidoI, J., Hori, H. \& Osawa, S. (1984). Secondary structure and phylogeny of Staphylococcus and Micrococcus 5 S rRNAs. Journal of Bacteriology 159, 233-237.
Donis-Keller, H. (1980). Phy $M$ : an R Nase activity specific for $U$ and A residues useful in RNA sequence analysis. Nucleic Acids Research 8, 3133-3142.

GladeK, A., Mordarski, M., Goodfellow, M. \& Williams, S. T. (1985). Ribosomal ribonucleic acid similarities in the classification of Streptomyces. FEMS Microbiology Letters 26, 175-180.

GoOdFellow, M. \& O'DonNell, A. G. (1989). Search and discovery of industrially-significant actinomycetes. Society for General Microbiology Symposia 44, 343-383.

Goodfellow, M., Williams, S. T. \& Alderson, G. (1986a). Transfer of Chainia species to the genus Streptomyces with emended descriptions of species. Systematic and Applied Microbiology 8, 55-60. Goodfellow, M., Williams, S. T. \& Alderson, G. (1986 $b$ ). Transfer of Elytrosporangium brasiliense Falcão de Morais et al., Elytrosporangium carpinense Falcão de Morais et al., Elytrosporangium spirale Falcão de Morais, Microellobosporia cinerea Cross et al., Microellobosporia flavea Cross et al., Microellobosporia grisea (Konev et al.) Pridham and Microellobosporia violacea (Tsyganov et al.) Pridham to the genus Streptomyces, with emended descriptions of the species. Systematic and Applied Microbiology 8, 48-54.

Goodfellow, M., Williams, S. T. \& Alderson, G. (1986c). Transfer of Kitasatoa purpurea Matsumae and Hata to the genus Streptomyces as Streptomyces purpureus comb. nov. Systematic and Applied Microbiology 8, 65-66.

GoOdfellow, M., Williams, S. T. \& Alderson, G. (1986d). Transfer of Actinosporangium violaceum Krasil'nikov and Yuan, Actinosporangium vitaminophilum Shomura et al. and Actinopycnidium caeruleum Krasil'nikov to the genus Streptomyces, with amended descriptions of the species. Systematic and Applied Microbiology 8, 61-64.

HORI, H. \& OSAWA, S. (1986). Evolutionary change in 5S rRNA secondary structure and a phylogenic tree of 352 5S rRNA species. BioSystems 19, 163-172. 
JONES, K. L. (1949). Fresh isolates of actinomycetes in which the presence of sporogenous aerial mycelia is a fluctuating characteristic. Journal of Bacteriology 57, 141-145.

Khan, M. R. \& Williams, S. T. (1975). Studies on the ecology of actinomycetes in soil. VIII. Distribution and characteristics of acidophilic actinomycetes. Soil Biology and Biochemistry 7, 345-348.

KIMURA, M. (1980). A simple method for estimating evolutionary rates of base substitutions through comparative studies of nucleotide sequences. Journal of Molecular Evolution 16, 111-120.

lane, D. J., Stahl, D. A., Olsen, G. J., Heller, D. J. \& Pace, N. R. (1985). Phylogenetic analysis of the genera Thiobacillus and Thiomicrospora by 5 S rRNA sequences. Journal of Bacteriology 163, $75-81$.

LONSDALE, J. (1985). Aspects of the biology of acidophilic actinomycetes. $\mathrm{PhD}$ thesis, University of Newcastle upon Tyne.

MacDonell, M. T. \& Colwell, R. R. (1985). Phylogeny of the Vibrionaceae, and recommendation for two new genera, Listonella and Shewanella. Systematic and Applied Microbiology 6, 171-182.

Park, Y.-H.. Hori, H., Suzuki, K.-I., Osawa, S. \& Komagata, K. $(1987 a)$. I hylogenetic analysis of the coryneform bacteria by $5 \mathrm{~S}$ rRNA sequences. Journal of Bacteriology 169, 1801-1806.

Park, Y.-H., Hori, H., Suzuki, K.-I., Osawa, S. \& Komagata, K. $(1987 b)$. Nucleotide sequence of $5 S$ ribosomal RNA from Rhodococcus erythropolis. Nucleic Acids Research 15, 365.

PeatTIE, D. A. (1979). Direct chemical method for sequencing RNA. Proceedings of the National Academy of Sciences of the United States of America 76, 1760-1764.

Rogers, M. J., Simmons, J., Walker, R. T., Weisburg, W. G., Woese, C. R., TanNer, R. S., Robinson, I. M., Stahl, D. A., Olsen, G., Leach, R. H. \& MaNilofF, J. (1985). Construction of the mycoplasma evolutionary tree from 5S rRNA sequence data. Proceedings of the National Academy of Sciences of the United States of America 82, 1160-1164.

Simoncsits, A. (1980). 3' Terminal labelling of RNA with beta- ${ }^{32} \mathrm{P}$ pyrophospate group and its application to the sequence analysis of $5 \mathrm{~S}$ RNA from Streptomyces griseus. Nucleic Acids Research 8, 41114124.

Stackebrandt, E., Ludwig, W., Seewaldt, E. \& Schleifer, K.-H. (1983). Phylogeny of sporeforming members of the order Actinomycetales. International Journal of Systematic Bacteriology 33, 173-180.

Tinoco, I., JR, Uhlenbeck, O. C. \& Levine, M. D. (1971). Estimation of secondary structure in ribonucleic acids. Nature, London 230, 362367.

Waksman, S. A. \& Henrici, A. T. (1943). The nomenclature and classification of the actinomycetes. Journal of Bacteriology 46, 337341 .

Williams, S. T., Davies, F. L., Mayfield, C. I. \& Khan, M. R. (1971) Studies on the ecology of actinomycetes. II. The pH requirements of streptomycetes from two acid soils. Soil Biology and Biochemistry 3, 187-195.

Williams, S. T., Goodfellow, M., Alderson, G., Wellington, E. M. H., SNeath, P. H. A. \& SaCkin, M. J. (1983). Numerical classification of Streptomyces and related genera. Journal of Gereral Microbiology 129, 1743-1813.

Williams, S. T., Goodfellow, M. \& Alderson, G. (1989). Genus Streptomyces Waksman and Henrici 1943, 339 AL. In Bergey's Manual of Systematic Bacteriology, vol. 4, pp. 2452-2492. Edited by S. T. Williams, M. E. Sharpe \& J. G. Holt. Baltimore: Williams \& Wilkins. 